\title{
SPATIAL AND SOCIAL CHANGES CAUSED BY THE CONTINUOUS EXPLOITATION OF LIGNITE IN THE KOLUBARA LIGNITE BASIN, SERBIA
}

Smiljana Đukičin, Jasmina Đorđević, Jelena Milanković

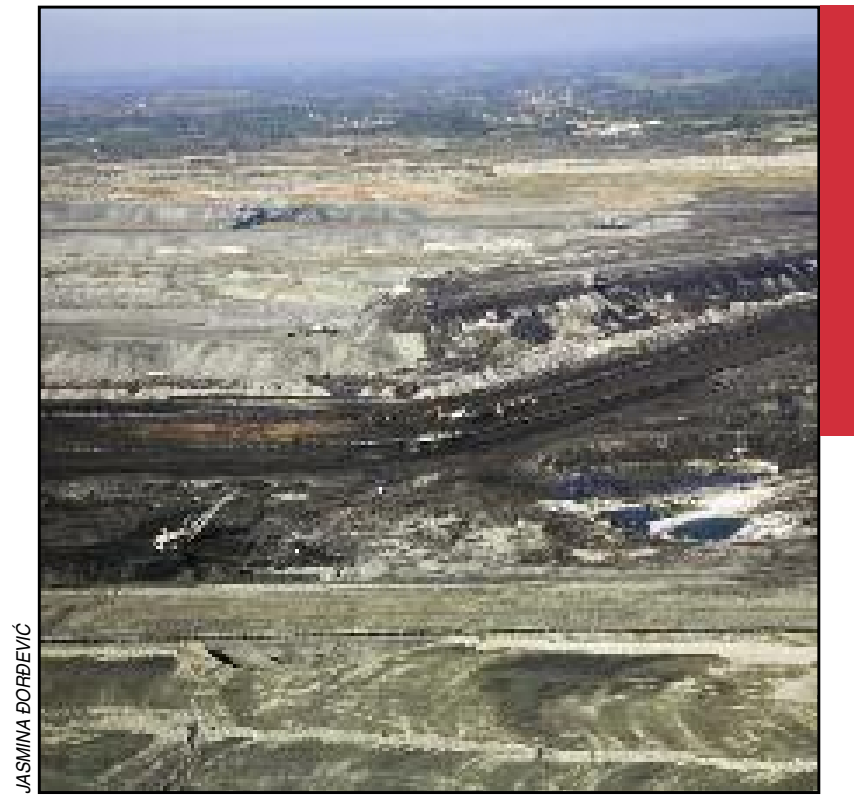

Kolubara Lignite Basin. 


\section{Spatial and social changes caused by the continuous exploitation of lignite in the Kolubara lignite basin, Serbia}

DOI: http://dx.doi.org/10.3986/AGS54102

UDC: 913:622.332(497.1)

COBISS: 1.01

ABSTRACT: The Kolubara Lignite Basin in the Republic of Serbia is the most important source of this type of fossil energy. Available lignite reserves enable the production of electricity, so the priority, in this region, is its exploitation. This is the reason why all other characteristics of this region have undergone major changes. Since the lignite exploitation started, the land use and river courses have changed in the region, local communities have been moved out, the settlements, infrastructure and human activity have been altered. The whole landscape acquired a completely different image. The social aspect is a sensitive and delicate feature, but the regulation of the region is also significant. Local population in this region has faced a set of social, cultural and economic problems.

KEY WORDS: mining, space transformation, regional development, demographic changes, Serbia

The article was submitted for publication on October 12, 2012.

ADDRESSES:

Smiljana Đukičin

University of Novi Sad

Faculty of Sciences

Department of Geography, Tourism and Hotel Management

Trg Dositeja Obradovića 3, 21000 Novi Sad

E-mail: smiljanadjukicin@gmail.com

Jasmina Đorđević, Ph. D.

University of Novi Sad

Faculty of Sciences

Department of Geography, Tourism and Hotel Management

Trg Dositeja Obradovića 3, 21000 Novi Sad

E-mail: jasminadjordjevic@live.com

Jelena Milanković

University of Novi Sad

Faculty of Sciences

Department of Geography, Tourism and Hotel Management

Trg Dositeja Obradovića 3, 21000 Novi Sad

E-mail: milankovicj@hotmail.com 


\section{Introduction}

The influence of mine basins on the environment can be observed through an identification and relativization of development conflicts and harmonization of different conflict interests in the organization and the utilization of the space. In general, almost all the changes which emerge as a result of the impact of mining on the environment are of spatial character. Spatial changes comprise of changes such as taking up huge areas of land for the development of pits, relocation of a watercourse and major traffic and other infrastructures and organization of new settlements for moving the population out of the mining area (Spasić et al. 2009). Spatial changes are also defined as degraded fields or land, woodland, geothermal water or other natural elements which have been modified by mining. Cultural potentials which can be modified by the mining include technological heritage, infrastructure, production facilities and housing (Marot and Harfst, 2012). During the process of claiming land for the purpose of surface exploitation, a conflict between of two important activities which are equally treated in most countries: the production of mineral raw materials and the production of food (Spasić et al. 2005).

Lignite represents, undoubtedly, the most significant energetic potential of the Republic of Serbia. In the Kolubara Basin, there are $20 \%$ of geological or exploitation reserves, and the degree of the activity of the deposits is $35 \%$. The availability of the lignite reserves on a relatively small area such as the Kolubara Basin makes it possible to open big pits by keeping the right attitude towards the environment and respecting the principles of economic and rational production of energy. The Mining Basin »Kolubara is the biggest producer of lignite in Serbia with 28-29 million tons a year, which represents $70 \%$ of all the coal produced in Serbia (The Spatial Plan ... 2008). A significant factor of development on state, regional and town scope is industry, so a great attention should be paid to its location. Well developed areas with properly built infrastructure, abundance of work force and facilities for developers are preferable compared to less developed regions (Đukičin et al. 2011).

In Eastern Europe the move of post-communist countries to democracy and markets is unanimously described as »transition «. The theory of transition, therefore, is a natural starting point for understanding post-communist change (Nedović-Budić et el. 2011).

The process of industrialization and urbanization refers to the cities and their environments, and it is considered to be the most significant element in the transformation of the geographical environment. The changes in the geographical environment are reflected through the increase of population in the cities, workforce migrations in the direction village-city, transformations in the physiognomic features of cities and their surrounding settlements. The impact of the lignite exploitation on the geographical environment can be observed in the changes in functional structure in cities and their surroundings, as well as in demographic elements. Spatial changes also comprise a set of social changes (Smiljanić 2002).

This paper shows spatial and social changes in the Kolubara Lignite Basin which have been created as a result of lignite exploitation and accelerated development of the mentioned area. Due to these trends, the population of the area was exposed to numerous demographic, social and economic changes, which will be presented in the paper. A section of the paper presents the results of a questioning conducted among the population of the settlements situated in the Kolubara Basin.

The underlying conditions of lignite mining and utilisation are characterised in the main by the energy management and energy-policy situations and, in particular, the underlying conditions on site - ie in the vicinity of the lignite mines.

In Germany, lignite is the most important domestic and subsidy-free source of energy, which, with a share of about one quarter, constitutes a key cornerstone of the energy mix used for power generation (Kulik and Drijver 2012). If the German concept of joint resettlement, mine planning and mining engineering, water management, were applied in Kolubara Basin in any form, many social and demographic problems would be avoided. Romania also was faced with lignite exploitation and resettlement in Oltenia. So far, as a result of the lignite open cast opening and extension there were resettled 2200 households, 40 social and cultural constructions (Fodor 2010). Slovenia also has long experience about lignite exploitation in Velenje (Markič and Sachsenhofer 2010). Velenje region has interesting, preserved natural landscapes, which are suitable for a range of recreational activities and tourism development (Marot and Harfst 2012; Komac et al. 2011; Hose et al. 2011). 


\section{The research area}

The area where exploitation of lignite is conducted in the Kolubara Basin lies $50 \mathrm{~km}$ to the south-west of Belgrade, which contributes to its favourable location. The most significant traffic route is the Kolubara River which vertically cuts across the area with the road of first degree and railway route Belgrade-Bar. Moreover, there are numerous smaller regional roads as well as a network of local roads (Todorović and Miletić 2007).

The main determinant factors in the success of a region are the fulfilment of the conditions for a good social and economic environment, while it is undoubtedly the case that a healthy environment favouring the growth and deployment of entrepreneurial skills develops more easily in settlements located nearer to larger centres (Ernits 2003). Environment in the Kolubara Basin is not healthy and there are many social and economic disparities. The industrial, mining and energy centres zones/belts and settlements in the proximity of traffic corridors and the major urban centres represent areas burdened by numerous environmental problems such as contaminated industrial land, degraded land in the zones of exploitation of mineral raw materials, polluted water and air, plus unsustainable waste management (Miljanović et al. 2010).

\section{Spatial changes due to lignite exploitation}

Major differences in well-being among territorial units at subnational level impede the progress of society and may cause economic, social, urban, environmental and political problems. Acknowledging of regional differences in well-being is of key importance for efficient planning and implementation of regional and spatial policy measures. The most significant conflict of mining industry with the environment in the Kolubara Basin refers to occupying agricultural and forest land in the process of surface exploitation. The occupation of land can be permanent or temporary during the exploitation, provided that recultivation brings it back to its original use (Spasić et al. 2005).

The exploitation area of the Kolubara Basin is a dynamic environment where land use changes because of the development of mining activity. According to certain dynamics, the front of mining activity moves, occupying new areas of settlements for the purpose of mining and organisation of traffic and infrastructural corridors, and parts of the pits, where exploitation is finished, are used as dump areas. Dump areas which are completely filled up are technically and biologically recultivated (Spasić et al. 2009).

Terrain inclination and the slope processes are the causes for the occurrence of the landslides and high-intensity soil erosion (Dragicevic et al. 2011; Dragićević et al. 2012).

During the opening of surface pits in the Kolubara Basin, the process of decreasing groundwater levels was conducted in close vicinity of pits, thus preventing the inflow of groundwater in the work area of the pit. The level of groundwater has decreased (Spasić et al. 2005).

Based on the Plan of General Regulation of the Settlement Vreoci, changes in land use in the central part of the Kolubara Basin up to 2020 will be most evident in the mining and agricultural sectors. In the eastern part of the Kolubara Basin, agricultural land will also expand but not as much as areas used for mining, since large-scale exploitations are planned. Spatial changes happening due to lignite exploitation in the Kolubara Basin, in addition to changes of land, land use and the groundwater levels, also cause changes in riverbeds.

In the Kolubara Basin, there have been major relocations of the Kolubara riverbed as well as regulations of its watercourse (Spasić et al. 2009). The first huge intervention in Kolubara river system happened in 1959, when the Kolubara's riverbed was diverted into its right tributary Pestan River. Those construction works were done for the purpose of lignite exploitation, which permanently influenced the entire process of fluvial erosion: stronger bank erosion resulted in larger amounts of sediment yield (Roksandic et al. 2011). The Kolubara river has been relocated further and regulated because of the opening of the pit »TamnavaIstočno polje«. In the period 1975-1977, the relocation and regulation of the Kolubara was conducted within the opening of the surface pit »Tamnava - Istočno polje« and its protection from flooding. The performed protection activity of SP »Tamnava - Istočno polje « against floods from the Kolubara and its left tributaries, the river Vraničina and the brook Skobalj, consists of relocating the Kolubara riverbed in the area from the railway bridge Vreoci - Obrenovac $(\mathrm{km} 28+880)$ to the Vraničina estuary $(\mathrm{km} 37+380)$ and building protective embankments. Significant morphological changes on the Kolubara and Peštan 

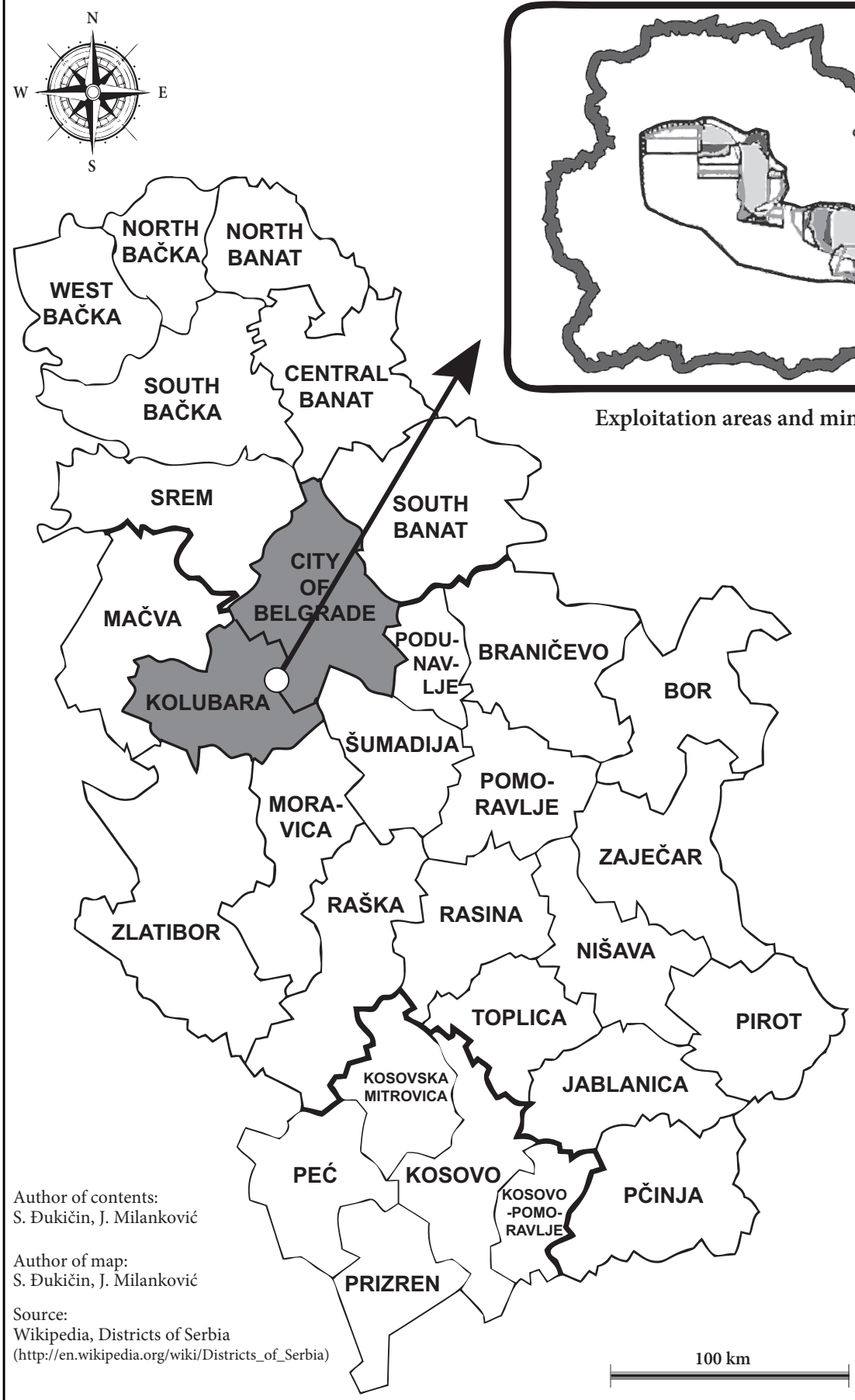

Figure 1: The position of the Kolubara Lignite Basin (Internet 1). 


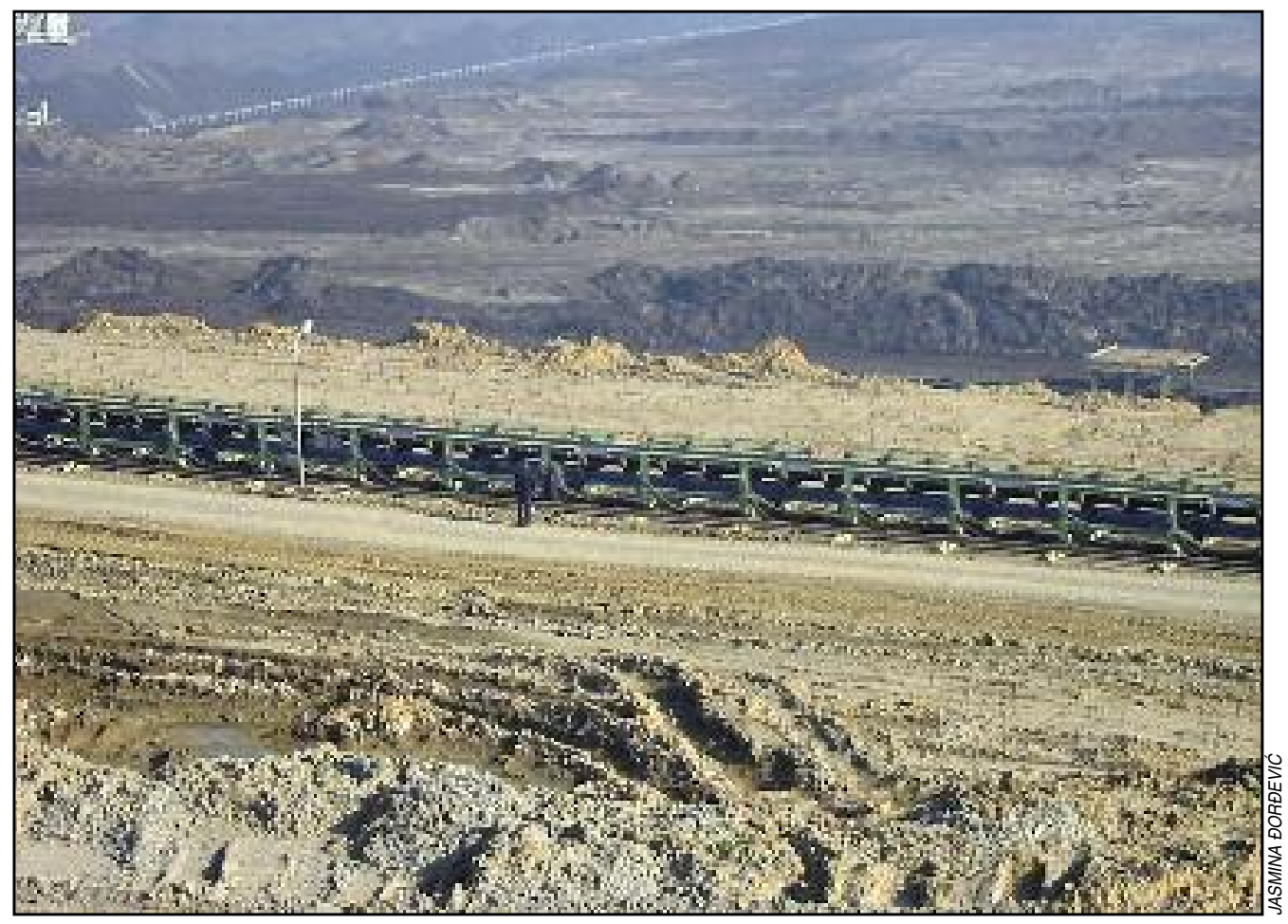

Figure 2: Kolubara D field.

happened in 1976. Moving the course of the Kolubara was aimed at widening the strip mining of lignite (Dragićević et al. 2007).

The River Peštan was regulated in its lower course, from the Kolubara estuary $(\mathrm{km} 0+000)$ to the railway bridge Belgrade - Bar $(\mathrm{km} \mathrm{3+070)}$ in 1981. In the regulated riverbed of the river Peštan, from the Kolubara estuary and the Ibar motorway, on the kilometre $1+065$ a cascade was built to control vertical alignment and the completely regulated riverbed in the upstream direction (Dragićević et al. 2007).

\section{Social changes in the Kolubara lignite basin}

Relocating population from the exploitation area in the Kolubara Basin certainly represents the most significant and the most sensitive change occurring due to a radical development of the industry and economy. Based on numerous questioning (surveys were done by the authors) in this field of study, it has been concluded that the population experiences this relocation as an imposition and expresses deep dissatisfaction with it. Over half of the population had to change their profession after relocation, and a huge number of them were left jobless.

Changes in demography affect different aspects of both urban and rural areas. Sudden increases in the population may lead to a complete disorganisation of a city or even of a village (Pereira Dra et al. 2010). The exploitation of lignite in the Kolubara Basin started in 1896, and the first open pit mining started in 1952. The largest resettlements began in the last decade of the $20^{\text {th }}$ century when 1614 households were relocated out of the zone of open pits development (Spasić et al. 2009). According to the Plan of General Regulation for the settlements of Vreoci, Zeoke, Medoševac and Burovo (2008) up to 2020, the most intensive relocations will be conducted in the settlements of Vreoci (1006 households), Zeoke (177 households), Medoševac (145 households) and Burovo (43 households) (Lukić and Matijević 2006). 


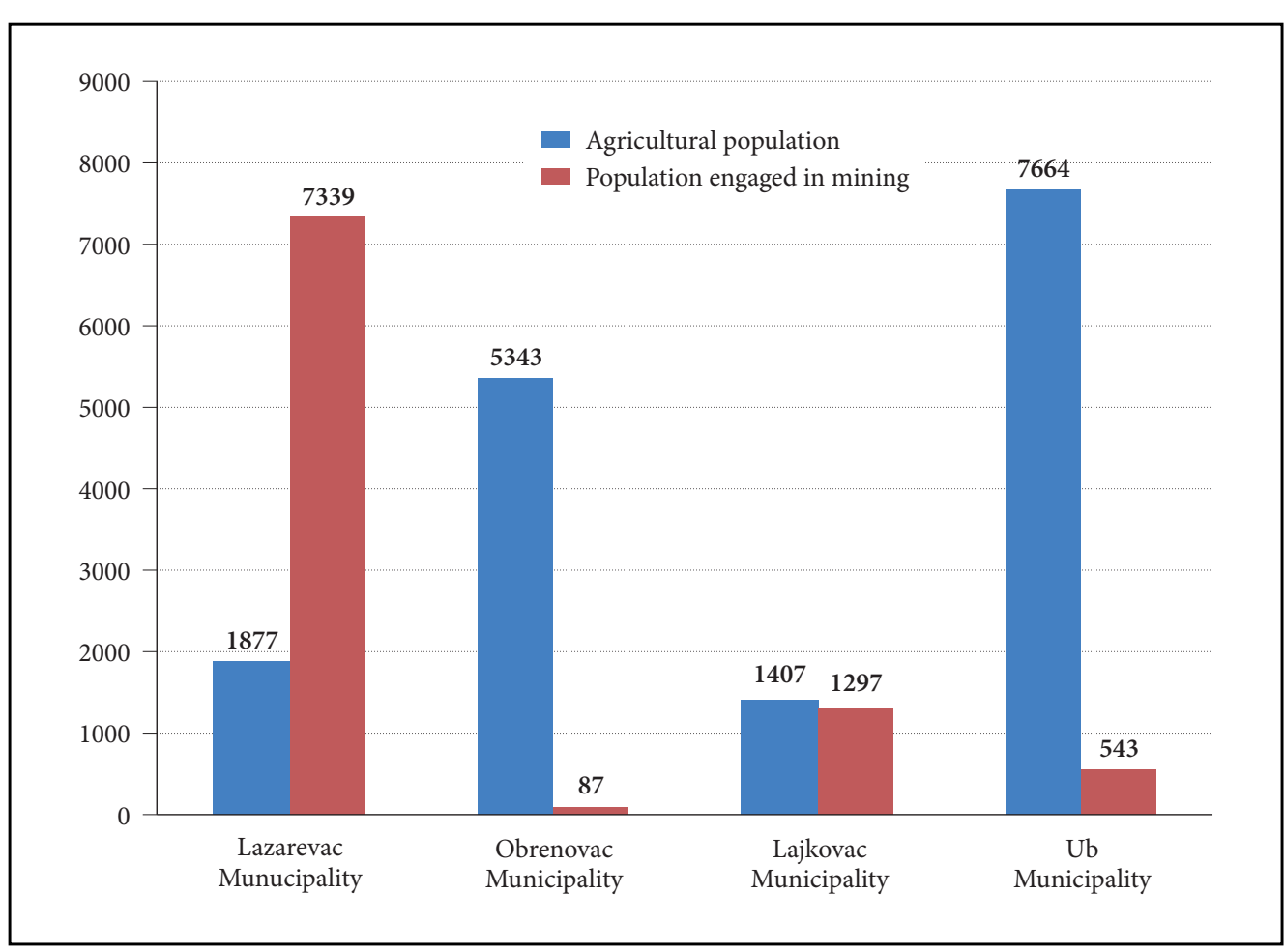

Figure 3: Agricultural population and population engaged in mining according to 2002 census (Republički zavod za statistiku ... 2004).

Since the most intensive relocation of the population has been conducted and planned in the settlement of Vreoci in the municipality of Lazarevac, the phenomenon of relocation will be specially treated in the case study of this settlement which can be used as guidelines for all other settlements with similar plans.

The population of Vreoci has largely urban socio-economic features, with a relatively high level of activity for both genders, aging processes, etc. Most of the employees work in one of the facilities of the Mining Basin »Kolubara «. Relocations were conducted through the process of expropriation, most often through payments for the taken properties, and the households had to solve the problem of the new place of residence on their own. By 2015, 95\% of population from Vreoci will be resettled, and 18\% from settlement Šopić (The Plan of General ... 2008).

Accelerated process of demographic aging of the population will cause further disappearance of single households, which will contribute to the fall in the total number of village households which are affected not only with this problem, but also with the problem of relocation (Lukić and Matijević 2006).

Twenty of respondents were interviewed at their homes. They were asked about their social and economic situation. Due to aging, relocation and negative population growth in the settlements of the Kolubara Basin, a series of demographic, social and economic problems are projected in the next periods. In the relocation of the population, the most affected are people without qualifications and those who are not ready enough to adjust to a new environment. During the research among the population for the purpose of this paper, they stated that they received large sums of money for the expropriated properties, but at the same time they lost the roof over their heads. In this manner, a great number of people without adequate qualifications are threatened to become social cases. In addition to demographic problems in the process of intensive exploitation, there are key changes in the network of settlements. Disturbing the functional organisation of settlements and traditionally formed village communities is a special problem which, in spite of material and other reimbursements, can be resolved only by the change in generations (Spasić et al. 2007). 
Finding locations for new settlements represents a very complex process, regarding the fact that the relocation of settlements is accompanied by problems related to: redistribution of functions among settlements, resulting in the transformation of the network of settlements; limited possibilities of resettlement of the mining basin after the completed exploitation, resulting in an uninhabited area; the stability of the landfills after the completion of mining works; the fact that the population does not want to be relocated to remote locations, which represents a problem because in large lignite basins, the pits are usually developed continually along a huge territory; and the principles of rationality which impose relocation of the population within the existing settlements. This decreases investment in settlement organisation and the construction of buildings with public functions, but there is also a problem of accepting new population by the domestic population, i. e. the adaptation of the new population (Spasić et al. 2009).

\section{Conclusion}

Modern human activity often influences the change of the space. Most often these changes are stressful for the spatial and social elements. In addition to planned projects and activities, it is not rare to have some failures. Exploitation in the Kolubara Lignite Basin is on the list of priorities because of its significance. This attitude of responsible institutions in Serbia causes permanent and radical changes in the area. A question is often asked if it is good to transform an area so that its land use and river courses are drastically changed, population relocated? What are the effects of these endeavours and what is the future for such an area?

Due to lignite exploitation, settlements were relocated, and the population faced numerous social and economic problems. The Republic of Serbia is the country which has not overcome the transition yet and which still does not have economic and other instruments to help it handle conflict situations like the one in the Kolubara Basin in the right way. The need for energy products exploitation is understandable, but, at the same time, relocation of the population and settlements should not be dealt with so easily. Due to one activity in an area, other activities should not be neglected. All activities should be conducted according to a plan, with good calculations and with the least number of negative effects. The Kolubara Basin is not the best example of these activities. In these activities Serbia should follow the example of well organised lignite exploitation country like Germany (Kulik and Drijver 2012).

\section{Acknowledgement}

This paper was financed by Project 176020 of the Serbian Ministry of Education, Science and Technological Development, and by Project (114-451-1861/2011-02) of the Provincial Secretariat of Science and Technological Development of the Vojvodina Province.

\section{References}

Dragićević, S., Carević, I., Kostadinov, S., Novkovic, I., Abolmasov, B., Milojković, B., Simić, D. 2012: Landslide susceptibility zonation in the Kolubara river basin (western Serbia) - analisys of input data. Carpathian Journal of Earth and Environmental Sciences 7-2.

Dragicevic, S., Filipovic, D., Kostadinov, S., Ristic, R., Novkovic, I., Zivkovic, N., Andjelkovic, N., Abolmasov, B., Secerov, V., Djurdjic, S. 2011: Natural Hazard Assessment for Land-use Planning in Serbia. International journal of environmental research 5-2.

Dragićević, S., Živanović, N., Ducić, V. 2007: Faktori nastanka poplava na teritoriji opštine Obrenovac. Zbornik radova - Geografski fakultet Univerziteta u Beogradu 55. Beograd.

Ernits, R. 2003: Location as the reason for the problems of old industrialised settlements. European journal of spatial development 4 . Stocholm.

Fodor, D. 2010: Mining industry and environment. Revista Minerol 16-8. Petrosani.

Hose, T., Marković, S., Komac, B., Zorn, M. 2011: Geotourism - a short introduction. Acta geographica Slovenica 51-2. DOI: http://dx.doi.org/10.3986/AGS51301

Internet 1: http://en.wikipedia.org/wiki/Districts_of_Serbia (10.1.2012) 
Komac, B., Zorn, M., Erhartič, B. 2011: Loss of natural heritage from the geomorphological perspectiveDo geomorphic processes shape or destroy the natural heritage? Acta geographica Slovenica 51-2. DOI: http://dx.doi.org/10.3986/AGS51305

Kulik, L., Drijver, J. 2012: Holistic planning and approval of sustainable lignite mining and utilisation. Coal International 260-2.

Lukić, V., Matijević, D. 2006: Demografski i prostorno - funkcionalni procesi u seoskim naseljima Ljiga. Zbornik radova geografskog instituta »Jovan Cvijić«, SANU 55.

Markič, M., Sachsenhofer, R. 2010: The Velenje lignite - its petrology and genesis. Ljubljana.

Marot, N., Harfst, J. 2012: Post-mining potentials and redevelopment of former mining regions in Central Europe - Case studies from Germany and Slovenia. Acta geographica Slovenica 52-1. Ljubljana. DOI: http://dx.doi.org/10.3986/AGS52104

Miljanović, D., Miletić, R., Đorđević J. 2010: Regional inequality in Serbia as a development problem. Acta geographica Slovenica 50-2. DOI: http://dx.doi.org/10.3986/AGS50204

Nedović-Budić, Z., Djordjevic, D., Dabović, T. 2011: The Mornings after ... Serbian Spatial Planning Legislation in Context. European planning studies 19-3.

Pereira Dra, D., Recio, S. and Gonsalo, J. C. 2010: Evolution of the landscape as a response of a demographic change. A case study in the Duero riverside, Spain. Local environment 15-5.

Plan generalne regulacije za naselje Vreoci 2008 Beograd: Službeni glasnik grada Beograda 54.

Plan generalne regulacije naselja Medoševac, Zeoke i Burovo 2008 Beograd: Službeni glasnik grada Beograda 58.

Prostorni plan područja eksploatacije Kolubarskog lignitskog basena 2008 Beograd: Službeni glasnik Rebuplike Srbije 122.

Republički zavod za statistiku 2004 Beograd: Delatnost i pol aktivnog stanovništva koje obavlja zanimanje knjiga 6.

Roksandic, M., Dragicevic, S., Zivkovic, N., Kostadinov, S., Zlatic, M., Martinovic, M. 2011: Bank erosion as a factor of soil loss and land use changes in the Kolubara River Basin, Serbia. African journal of agricultural research 6-32.

Smiljanić, Z. 2002: Savremene tendencije procesa urbanizacije Kolubarskog okruga. Zbornik radova Geografski fakultet Univerziteta u Beogradu 50.

Spasić, N., Petovar K., Jokić V. 2007: Transformation of Settlements and Population in large lignits Basins. Spasić, N., Stojanović, B., Nikolić, M. 2005: Uticaj rudarstva na okruženje i revitalizacija degradiranog prostora. Arhitektura i urbanizam 16-17.

Spasić, N., Džunić, J., Đurđević, J. 2009: Konflikti i ograničenja u prostornom razvoju rudarskih basena. Arhitektura i urbanizam 27.

Todorović, M., Miletić, R. 2007: Korišćenje zemljišta u Valjevskim selima Bujačić, Klinci i Petnica. Zbornik radova Geografskog instituta »Jovan Cvijić« SANU 56.

Đukičin, S., Milanković, J., Đorđević, J. 2011: Contemporary Business Trends and Industrial Transformation in Slovenia on the Examples of Maribor and Celje. Geographica Pannonica 15-3. 
